\title{
Gentamicin Therapeutic Drug Monitoring: Importance in the Hospital Setting
}

T Mason ${ }^{1}, \mathrm{M} \mathrm{Verley}^{1}, \mathrm{M}$ Gossell-Williams${ }^{1}$, A Thorbourne ${ }^{2}$, A Walcott-Mitchell², K Hoe ${ }^{3}$, M Lee ${ }^{3}$

\section{ABSTRACT}

\begin{abstract}
Background: The use of gentamicin places patients at risk of developing drug-induced nephrotoxicity, requiring special consideration to be given to serum creatinine monitoring and therapeutic drug monitoring (TDM).
\end{abstract}

Objectives: To evaluate the prevalence of nephrotoxicity without the availability of TDM.

Methods: A prospective study was used to recruit patients, 18 years and older who were to receive intravenous gentamicin administration between July 2013 and July 2014 at the University Hospital of the West Indies. Their data collected included: demographics, type of infection, gentamicin dose regimen, concomitant drugs and serum creatinine. Nephrotoxicity was defined as 1.5 times or more increase in serum creatinine concentration above the baseline.

Results: Eleven patients were included in the study; six (55\%) were males, their median age was 51 years (range: 33-84 years). All the patients had normal baseline serum creatinine, median 56 (range: 22-94) $\mu \mathrm{mol} / \mathrm{L}$ and had regular monitoring of serum creatinine during therapy. The median gentamicin dose was $160 \mathrm{mg} /$ day (range: 50-240 $\mathrm{mg} /$ day) and median treatment length was eight days (range: 5-30 days). Evidence of nephrotoxicity was observed in six (55\%) patients by day seven of therapy. All the patients had at least one risk factor predisposing them to nephrotoxicity including prolonged therapy (10/11), multiple daily dosing regimen (8/11), receiving concomitant nephrotoxic drugs (9/11) and age (6/11).

Conclusion: Although vigilant monitoring of serum creatinine is useful for safety monitoring, with most patients experiencing some levels of nephrotoxicity and having at least one predisposing risk factor, consideration should be given to the implementation of TDM.

Keywords: Gentamicin, therapeutic drug monitoring, serum creatinine

\section{Monitoreo Farmacoterapéutico de la Gentamicina: Importancia en el Ámbito Hospitalario}

T Mason ${ }^{1}$, M Verley ${ }^{1}$, M Gossell-Williams ${ }^{1}$, A Thorbourne ${ }^{2}$, A Walcott-Mitchell ${ }^{2}, \mathrm{~K} \mathrm{Hoe}^{3}, \mathrm{M} \mathrm{Lee}^{3}$

\section{RESUMEN}

Antecedentes: El uso de la gentamicina pone a los pacientes en riesgo de desarrollar nefrotoxicidad inducida por medicamentos, por lo cual se requiere ofrecer especial considera-ción a la monitorización de la creatinina en suero y al monitoreo terapéutico de fármacos (MTF).

Objetivos: Evaluar la prevalencia de la nefrotoxicidad sin la disponibilidad de MTF.

Métodos: Se utilizó un estudio prospectivo para reclutar pacientes de 18 años y más, quienes debian recibir la administración de gentamicina intravenosa entre julio de 2013 y julio de 2014 en el Hospital Universitario de West Indies. La información obtenida de ellos incluyó: datos demográficos, tipo de infección, régimen de dosis de gentamicina, medicamentos con-comitantes, y creatinina sérica. La nefrotoxicidad se definió como un aumento de 1.5 veces o más, de la con-

From: ${ }^{1}$ Department of Basic Medical Sciences, The University of the West Indies, Kingston 7, Jamaica. ${ }^{2}$ University Hospital Pharmacy, University Hospital of the West Indies, Kingston 7, Jamaica and ${ }^{3}$ Department of Medicine, The University of the West Indies, Kingston 7, Jamaica.
Correspondence: Dr M Gossell-Williams, Pharmacology Section, Department of Basic Medical Sciences, The University of the West Indies, Kingston 7, Jamaica. Email: maxine.gossell@uwimona.edu.jm 
centración de creatinina sérica por encima de la línea de base.

Resultados: Once pacientes fueron incluidos en el estudio; seis (55\%) eran varones, su edad promedio fue 51 años (rango: 33 - 84 años). Todos los pacientes tuvieron la creatinina sérica basal normal, promedio $56 \mu \mathrm{mol} / \mathrm{L}$ (rango: 22-94), y recibieron control periódico de la creatinina sérica durante la terapia. La dosis de gentamicina promedio fue $160 \mathrm{mg} /$ dia (rango: 50 a 240 $\mathrm{mg} /$ dia), y la duración promedio del tratamiento fue ocho dias (rango: 5 - 30 días). Se observó evidencia de nefrotoxicidad en 6 pacientes (55\%) en el séptimo día de la terapia. Todos los pacientes tuvieron al menos un factor de riesgo que les predisponía a la nefrotoxicidad, incluyendo terapia prolongada (10/11), régimen de dosificación diaria múltiple (8/11), administración de medicamentos nefrotóxicos concomitantes (9/11), y edad (6/11).

Conclusión: Aunque el monitoreo vigilante de la creatinina sérica es útil para efectuar controles de seguridad, por cuanto la mayoría de los pacientes experimentan algunos niveles de nefrotoxicidad y tienen un factor de riesgo predisponente, debe tomarse en consideración la implementación de MTF.

Palabras claves: Gentamicina, monitoreo terapéutico de fármacos, creatinina sérica

West Indian Med J 2017; 66 (2): 325

\section{INTRODUCTION}

Gentamicin is an aminoglycoside antibacterial used for the treatment of septicemia and other serious infections (1). A limitation of its use is the narrow therapeutic index and its propensity to induce nephrotoxicity (2). Nephrotoxicity is often associated with poor outcomes and an increased mortality rate (3).

Gentamicin induced nephrotoxicity is usually assessed by the monitoring of the change in serum creatinine in patients (4). The risk, injury, failure, loss, end-stage renal disease (RIFLE) criteria proposed by the acute dialysis quality initiative (ADQI) group classifies acute renal dysfunction in five different classes, namely: R (Risk), I (injury), F (failure), L (loss) and E (end-stage kidney disease) and has been used to monitor acute change in renal function during gentamicin therapy (5).

Complementary to the monitoring of the serum creatinine is the therapeutic drug monitoring (TDM) of serum gentamicin level, TDM facilitates the assessment of the peak serum gentamicin level which is the indicator of its efficacy, while the trough level is implicated in the toxic effect $(6,7)$. The measurement of the drug levels in the serum and the application of pharmacokinetic principles have greatly improved patient care. Positive results, such as decreased nephrotoxicity, reduced length of hospital stays and improved clinical response with a decrease in the number of days with signs of infection have been reported $(8,9)$. However, other current studies have suggested that TDM may not be of additional clinical benefit in all patients. It has been suggested that TDM of gentamicin in critically ill patients is not re- quired if the renal function is normal. But it is required if there is concomitant nephrotoxic drugs administration, if the patient is $\geq 60$ years, if there are other co-morbidities (eg cardiovascular diseases and diabetes mellitus) or if therapy is longer than five days $(10,11)$.

In the settings where TDM is not available, the assessment of serum creatinine is important to ensure the safe use of aminoglycoside. The reliance on serum creatinine only requires monitoring every other day (10). This study examined the frequency of nephrotoxicity among adult patients receiving intravenous gentamicin at the University Hospital of the West Indies (UHWI) and the presence of the common risk factors known to be associated with gentamicin induced nephrotoxicity.

\section{METHODS}

This study was reviewed and approved by the University Hospital of the West Indies/The University of the West Indies/Faculty of Medical Science/Ethic Committee (ECP 271, 12/13, June 17, 2013). The patients admitted to the UHWI who received gentamicin therapy between July 2013 and July 2014 were eligible for study. The inclusion criteria for the study include: patients 18 years and older, who were administered gentamicin through intravenous infusion and consented to be part of the study. The patients receiving only a single dose of intravenous gentamicin and renal dialysis patients were excluded. Information was recorded regarding the patients' demographics (age, gender and weight), the indication for gentamicin use, and gentamicin dose and treatment period. 
Serum creatinine levels were assayed in the Chemical Pathology Department at the UHWI using the Cobas 6000 C510 Spectrometer. The baseline creatinine was recorded as the minimum of the first-three serum creatinine determinations upon the patients' admission, before the initiation of gentamicin therapy (3). The peak serum creatinine was recorded as the highest value during gentamicin treatment.

Nephrotoxicity was assessed using serum creatinine as defined by the RIFLE criteria, defined as serum creatinine increases of at least 1.5 times the baseline value (12). The presence of the risk factors associated with nephrotoxicity was also assessed. Discrete variables were reported as counts with percentages; continuous data were expressed as means and standard deviations (SDs) and median (with range) unless otherwise stated. The Wilcoxon-test was used for inferential statistics paired comparison with $p<0.05$ considered as significant. The data was analysed using the Statistical Package for the Social Sciences (SPSS) version 20.0.

\section{RESULTS}

Eleven patients participated in this study. Six (54.5\%) of them were males; their median age was 51 years (range: $33-84)$. The weights of nine ( $82 \%)$ of the patients were recorded; the median was $62.9 \mathrm{~kg}$, (range 51.7 to 75.1 $\mathrm{kg}$ ). All the patients had at least one chronic disease condition including cardiovascular disease, diabetes mellitus, acute myeloid leukemia, acquired immunodeficiency syndrome, hypothyroidism and gouty arthritis (Table 1).

Table 1: Demographics of the patients studied

\begin{tabular}{ll}
\hline Unit & Total $(\mathbf{n}=\mathbf{1 1})$ \\
\hline Age (years) & \\
Mean \pm SD & $56.4 \pm 19.5$ \\
$\quad$ Median (range) & $51(33-84)$ \\
Patients $>65$ years n (\%) & $3(27.3 \%)$ \\
Weight $(\mathrm{kg})$ & \\
Mean \pm SD & $62.5 \pm 8.5$ \\
Median (range) & $62.9(51.7-75.1)$ \\
Gender & \\
Male n $(\%)$ & $6(54.5 \%)$ \\
Female n (\%) & $5(45.5 \%)$ \\
Type of infection & \\
$\quad$ Sepsis & $9(82 \%)$ \\
Infective endocarditis & $1(9 \%)$ \\
$\quad$ Urinary tract infection & $1(95)$ \\
Co-morbidities & \\
Diabetes mellitus & $3(27 \%)$ \\
Hypertension/ cardiovascular disease & $5(45 \%)$ \\
Acute myeloid leukaemia & $4(36 \%)$ \\
Acquired immune deficiency syndrome & $1(9 \%)$ \\
\hline
\end{tabular}

Sepsis $(82 \%)$ was the most common indication among the patients in this study. The specific indications reported were: septic shock due to a lower respiratory tract infection (11\%), neutropenic sepsis (33\%), hospital acquired pneumonia and urosepsis (11\%), sepsis due to infected decubitus ulcer (11\%), intra-abdominal sepsis (11\%) and septicemia (11\%). The causative organisms were isolated from the blood and/or urine samples for eight $(73 \%)$ of the patients. Among the isolated bacteria were: Pseudomonas aeruginosa, Coagulase negative staphylococcus, Klebsiella pneumoniae, Staphylococcus aureus, Escherichia Coli and Enterococus sp.

Eight $(73 \%)$ of the patients initially received gentamicin as empiric therapy and three $(27 \%)$ received therapy after microorganism identification. However, most of the isolated bacteria (91\%) were confirmed to be sensitive to gentamicin. The data on dosing are summarized in Table 2 along with the serum creatinine data.

Table 2: Gentamicin regimen, serum creatinine data and the presence of known risk factors for nephrotoxicity

\begin{tabular}{|c|c|}
\hline Item & Frequency $(\%)$ \\
\hline \multicolumn{2}{|l|}{ Dose (mg/day) } \\
\hline Mean $\pm \mathrm{SD}$ & $164.6 \pm 49.7$ \\
\hline Median (range) & $160(50-240)$ \\
\hline \multicolumn{2}{|l|}{ Baseline serum creatinine $(\mu \mathrm{mol} / \mathrm{L})$} \\
\hline Mean $\pm \mathrm{SD}$ & $59.6 \pm 23.0$ \\
\hline Median (range) & $56(22-94)$ \\
\hline \multicolumn{2}{|l|}{ Peak serum creatinine $(\mu \mathrm{mol} / \mathrm{L})$} \\
\hline Mean $\pm \mathrm{SD}$ & $108.5 \pm 77.3$ \\
\hline Median (range) & $78(45-316)^{*}$ \\
\hline \multicolumn{2}{|l|}{ Treatment duration (days) } \\
\hline Mean \pm SD & $10.8 \pm 6.8$ \\
\hline Median (range) & $8(5-30)$ \\
\hline $\begin{array}{l}\text { Serum creatinine }>1.0 \text { of baseline within five } \\
\text { days of start }\end{array}$ & $8(73 \%)$ \\
\hline Peak serum creatinine $\geq 1.5$ of baseline & $6(54.5 \%)$ \\
\hline \multicolumn{2}{|l|}{ Time to peak creatinine (days) } \\
\hline Mean $\pm \mathrm{SD}$ & $7.3 \pm 2.8$ \\
\hline Median (range) & $7(3-11)$ \\
\hline \multicolumn{2}{|l|}{ Risk factors for nephrotoxicity } \\
\hline Duration $>$ five days of gentamicin & $10(91 \%)$ \\
\hline Concurrent nephrotoxic drug\# & $9(82 \%)$ \\
\hline Multiple daily dose & $8(73 \%)$ \\
\hline Cardiovascular disease and/or diabetes mellitus & $6(55 \%)$ \\
\hline Age $\geq 60$ years & $5(45 \%)$ \\
\hline
\end{tabular}

${ }^{*} p>0.01$ when compare with baseline creatinine using Wilcoxon test. 
For dosing, the dose regimen most often employed was the multiple daily dosing regimen $(73 \%)$ with a median dose of $160 \mathrm{mg}$ /day (50-240 mg/day). Median treatment duration was eight days (5-30 days). The median serum creatinine at the baseline was $56 \mu \mathrm{mol} / \mathrm{L}$ (range: $22-94 \mu \mathrm{mol} / \mathrm{L}$ ), and the median peak serum creatinine was $78 \mu \mathrm{mol} / \mathrm{L}$ (range: $45-316 \mu \mathrm{mol} / \mathrm{L}$ ).

There was a significant rise in the patients' serum creatinine value from the baseline to peak during gentamicin therapy $(p<0.01)$. All the patients had serum creatinine assayed at least twice within five days. Eight of the patients had an increase in serum creatinine within five days from the start of gentamicin therapy and six $(55 \%)$ of the patients experienced a peak serum creatinine of $\geq 1.5$ times the baseline value. The median time interval from first gentamicin dose to peak serum creatinine was seven days (3 to 11 days).

The frequency of the risk factors that predispose patients to nephrotoxicity secondary to gentamicin therapy was assessed. Among the risk factors recorded, nine $(82 \%)$ of the patients were concomitantly administered at least one drug that is known to be nephrotoxic or likely to potentiate the nephrotoxicity of gentamicin. They included: ibuprofen, aspirin, lisinopril, furosemide, vancomycin, cefuroxime and ceftriaxone. Multiple daily dosing and a prolonged duration of therapy ( $>5$ days) were each evident in eight $(73 \%)$ and ten $(91 \%)$ of the patients, respectively. Five (45\%) of the patients were 60 years or older.

Five $(45 \%)$ of the patients died, four $(36 \%)$ of the surviving patients were cured of bacterial infection and two $(18 \%)$ had a remaining infection at the end of gentamicin therapy. Infection was listed among the cause of death in three $(60 \%)$ of the five fatalities. Of these three patients, one fatality occurred shortly after treatment failure due to gentamicin-resistant Klebsiella pneumonia. The other reported fatalities were documented as due to the co-morbid states previously mentioned.

Of the six patients who experienced nephrotoxicity, two had fatal outcomes. Renal impairment was not listed as cause of death in any of the two patients. The remaining patients showed a gradual decrease in serum creatinine values after their completion of gentamicin therapy. Based on the physician's recommendation, gentamicin was discontinued for one patient before the end of the prescribed treatment. This was in view of documented renal failure which developed 11 days after the initiation of gentamicin therapy. The percentage increase in serum creatinine in this patient was $166 \%$. The serum creatinine value, however, also trended towards the base- line values after the discontinuation of the gentamicin therapy.

\section{DISCUSSION}

The focus of this study was to evaluate the safety of intravenous gentamicin therapy in patients in the absence of TDM. All the patients had baseline serum creatinine within the normal range, thus suggesting normal renal function prior to the start of gentamicin. The gentamicin dosage received by these patients ranged from 50 to 240 $\mathrm{mg}$ /day and are consistent with the therapy in established guidelines. The monitoring of serum creatinine changes every other day was also consistent with the current guidelines for gentamicin therapy. Most of the patients, $55 \%$, had a peak creatinine concentration of 1.5 times or more which was attained in 5 to 11 days on gentamicin therapy, suggesting that some levels of nephrotoxicity occurred in most of the patients given intravenous gentamicin at UHWI. Additionally, for this study, the median period of treatment was eight days (5-30 days) and the median time to reach peak serum creatinine was seven days (3-11 days). Our findings therefore support previous evidence of the risk of gentamicin induced nephrotoxicity occurring within five days from the start of therapy (10).

It is recommended that TDM of aminoglycosides, such as gentamicin is advised under the following conditions: when there renal dysfunction; there are difficultto-treat infections; there is a prolonged duration of therapy; patients are on concomitant nephrotoxic medications and in patients of at least 60 years or if there are other co-morbidities [eg cardiovascular disease or diabetes mellitus] (11). All the patients in this study had at least one comorbid disease including hypertension and diabetes mellitus and most were on a concurrent drug with the potential to increase nephrotoxic risk including non-steroidal anti-inflammatory drugs and other antibacterials, such as vancomycin (13). The ageing renal physiology combined with the increasing co-morbidities and severity of disease, as well as multiple drug use, makes this sample at even greater risk for gentamicin induced nephrotoxicity (14). With the presence of at least one of these factors in each patient, the study suggests that although patients displayed normal renal function at the baseline, all the patients could have benefited from TDM to reduce the risk of nephrotoxicity occurring.

Multiple daily dosage is also known to likely predispose patients to nephrotoxicity than once daily dosage $(13,15)$. With most of the patients on multiple daily dosage (73\%) therapy rather than the once daily dose, the 
patients were at a greater risk of nephrotoxicity. In the absence of TDM, the careful monitoring of serum creatinine as a marker of renal function must be ensured and in the presence of evidence of renal changes, a review of drug regimen is indicated.

The findings of this study utilized the use of the serum creatinine as the only determinant of gentamicin induced nephrotoxicity. The causal relationship with gentamicin use would have been more definitive with the measurement of gentamicin serum levels. Additionally, the small sample size did not facilitate the actual calculation of the associations with the known risk factors for gentamicin induced nephrotoxicity.

\section{CONCLUSION}

Gentamicin remains important especially for the treatment of serious gram negative infections despite its known potential for nephrotoxicity. With more than half of the patients in this study experiencing some levels of nephrotoxicity within five days of the start of therapy, the evaluation of the other risk factors present in each patient should be considered. Adhering to established guidelines, especially in the absence of TDM may reduce nephrotoxicity's risk.

\section{REFERENCES}

1. Taccone FS, Hites M, Beumier M, Scolletta S, Jacobs Fdr. Appropriate antibiotic dosage levels in the treatment of severe sepsis and septic shock. Curr Infect Dis Rep 2011; 13: 406-15.

2. Mingeot-Leclercq MP, Tulkens PM. Aminoglycosides: nephrotoxicity. Antimicrob Agents Chemother 1999; 43: 1003-12.

3. Chertow GM, Burdick E, Honour M, Bonventre JV, Bates DW. Acute kidney injury, mortality, length of stay, and costs in hospitalized patients. J Am Soc Nephrol 2005; 16: 3365-70.
4. Perrone RD, Madias NE, Levey AS. Serum creatinine as an index of renal function: new insights into old concepts. Clinical Chem 1992; 38: 1933-53.

5. Medha AS, Pandey RM, Sawhney C, Upadhayay AD, Albert V. Incidence, clinical predictors and outcome of acute renal failure among North Indian trauma patients. J Emerg Trauma Shock 2013; 6: 21 .

6. Drusano GL. Pharmacokinetics and pharmacodynamics of antimicrobials. Clin Infect Dis 2007; 45 (Suppl 1): S89-95.

7. Burton, Michael E ed. Applied pharmacokinetics and pharmacodynamics: principles of therapeutic drug monitoring. Lippincott Williams \& Wilkins; 2006: 285-327.

8. van Lent-Evers NA, Math+ ${ }_{1}^{\mathrm{t}} \mathrm{RA}$, Geus WP, van Hout BA, Vinks AA. Impact of goal-oriented and model-based clinical pharmacokinetic dosing of aminoglycosides on clinical outcome: a cost-effectiveness analysis. Ther Drug Monit 1999; 21: 63-73.

9. Roberts JA, Norris R, Paterson DL Martin JH. Therapeutic drug monitoring of antimicrobials. Br J Clin Pharmacol 2012; 73: $27-$ 36.

10. Aminoglycoside use in critically ill patients requires careful regimen planning and drug monitoring to avoid nephrotoxicity. Drugs Ther Perspect 2013; 29: 282-6.

11. John Hopkins Medicine. Antibiotic Guidelines 2014-2015. Available from: http://www.hopkinsmedicine.org/amp/guidelines/Antibiotic_guid elines.pdf

12. Salgado G, Landa M, Masevicius D, Gianassi S, San-Román JE, Silva $\mathrm{L}$ et al. Acute renal failure according to the RIFLE and AKIN criteria: A multicenter study. Medicina Intensiva (English Edition) 2014; 38: 271-7.

13. Lopez-Novoa JM, Quiros Y, Vicente L, Morales AI, LopezHernandez FJ. New insights into the mechanism of aminoglycoside nephrotoxicity: an integrative point of view. Kidney Int 2011; 79: 33-45.

14. Fraisse T, Paccalin M, Vitrat V, De Wazieres B, Baudoux V, Lechiche $\mathrm{C}$ et al. Aminoglycosides use in patients over 75 years old. Age Ageing 2014; 43: 676-81.

15. Dhodi DK, Bhagat SB, Pathak D, Patel SB. Drug-induced nephrotoxicity. Int J Basic Clin Pharmacol 2014; 3: 591-7. 